\title{
Management of Fusarium wilt of tomato by bioagents, fungicides and varietal resistance
}

\author{
B.G. BARHATE, N.A. MUSMADE* AND T.A. NIKHATE
}

Department of Plant Pathology and Agricultural Microbiology, Mahatma Phule Krishi Vidyapeeth, Rahuri, AHMEDNAGAR (M.S.) INDIA

\section{ARITCLE INFO}

Received : 07.08 .2014

Revised : 17.01 .2015

Accepted : 01.02 .2015

\section{KEY WORDS :}

Tomato, Wilt, Fusarium oxysporum, Chemical, Biological control, Varietal resistance
*Corresponding author: Email: bgbarhate@gmail.com

\begin{abstract}
Tomato wilt caused by Fusarium oxysporum f.sp. lycopersici is most important and destructive disease of tomato in Maharashtra, which causes considerable losses in yield of tomato. Therefore, present studies were undertaken to test the efficacy of eight fungicides and six bioagents in vitro and ten varieties of tomato in green house against Fusarium wilt of tomato Among the eight fungicides, Mancozeb + Carbendazim $(0.125+0.05 \%)$ had completely checked the growth of pathogen which inhibited 100 per cent growth of Fusarium oxysporum f.sp. lycopersici followed by Thiram + Carbendazim $(0.15+0.05 \%)$, Carbendazim $(0.1 \%)$, Thiram $(0.3 \%)$, Carboxin $(0.2 \%)$, Captan $(0.25 \%)$, Propiconazole $(0.2 \%)$, Mancozeb $(0.25 \%)$ with $93.75,92.50$, $90.00,87.50,81.25,67.50$ and 62.50 per cent growth inhibition over control, respectively. In vitro, the antagonistic effect of four species of Trichoderma and two bacterial bioagents were tested against this pathogen. Among the four Trichoderma species tested, Trichoderma viride recorded highest growth inhibition $(85.00 \%)$ of Fusarium oxysporum f.sp. lycopersici followed by $T$. harzianum, $T$. hamatum, $T$. koningii with $72.50,70.00,61.12$ per cent growth inhibition over control, respectively and among two bacterial bioagents, Bacillus subtillis was found more effective than Pseudomonas fluorescens with 79.2 and 62.5 per cent growth inhibition over control. Among the ten varieties tested against Fusarium oxysporum f.sp. lycopersici in greenhouse, Bhagyashree and Dhanashree were found moderately resistant to wilt of tomato having 25.00 and 30.00 per cent disease incidence followed by RII-T-2, M-1-3, M-2-2, 8-15,NBC, 6-1, M-1-2 and RII-T1 with 55, 60, 60, 70, 70, 75, 80 and 85 per cent disease incidence, respectively.
\end{abstract}

How to view point the article : Barhate, B.G., Musmade, N.A. and Nikhate, T.A. (2015). Management of Fusarium wilt of tomato by bioagent, fungicides and varietal resistance. Internat. J. Plant Protec., 8(1) : 49-52. 